\title{
An Analysis of Humanitarian Military Intervention in Nigeria: Focus on Saving Victims or Defeating Boko Haram?
}

\author{
Tiffany Setyo Pratiwi ${ }^{1}$, Fherdy Ola Boli Bin Soge ${ }^{1}$ \\ ${ }^{1}$ Program Studi Hubungan Internasional, Universitas Teknologi Yogyakarta, Yogyakarta, \\ Indonesia \\ ${ }^{1}$ Program Studi Hubungan Internasional, Universitas Teknologi Yogyakarta, Yogyakarta, \\ Indonesia \\ tiffanysubarman@gmail.com
}

\begin{abstract}
This study explains humanitarian military intervention in Nigeria and analyzes how the intervener focuses on either the victims or perpetrators. Humanitarian intervention occurred because there had been massive human rights violations and privation. Boko Haram is a separatist group that attacks Nigeria especially in Borno, Adamawa, and Yobe. They want to replace Nigeria's legitimate government with Sharia Law. In 2020, the total number of deaths in Nigeria has reached an estimated amount of 39.249 people. Unfortunately, Nigeria has been unable to solve the problem. Those conditions need international actors to take action. The African Union is one of the actors that intervene in Nigeria's internal issue. In this study, the authors focuses on how the African Union acts as a regional organization in taking actions in Nigeria, whether they focus on victims or perpetrators, whether the African Union uses avoidance strategy, deterrence strategy, defense strategy, compellence strategy, or offence strategy. To answer those questions, this study will explain in two sub-chapters, first, explaining the development of Boko Haram's attack and second, analyzing humanitarian intervention efforts in Nigeria carried out by The African Union. The research method used in this study is descriptive-qualitative. The data are derived from literature study, books, and internet sources. This study found that African Union's intervention focuses on defeating Boko Haram and focuses on saving victims by providing aid. The strategy to defeat Boko Haram is with offense strategy carried out by the military unit Multi-National Joint Task Force (MNJTF). The strategy to deliver aid is through avoidance (no direct confrontation) and $\mathrm{AU}$, as well as collaboration with UN, UNHCR, ICRC, and other international humanitarian actors.
\end{abstract}

Keywords: Boko Haram, Humanitarian Military Intervention, Nigeria.

\section{INTRODUCTION}

The conflict in Nigeria started after its independence in 1967. This conflict was called the "Biafran War". A long war has left Nigeria unstable. Data from the World Poverty Clock identified that Nigeria as the highest extreme poverty rate in the world in 2018, even beating and replacing India as a country that was ranked second, also previously ranked first as a country with an extreme poverty rate (World Poverty Clock, 2018).

The war of Biafra is not completely over yet, but Nigeria is already facing new challenges. Boko Haram or which originally had the name Jama'atu Ahlis Sunna Lidda'awati Wal-Jihad - the literal translation from Arabic means "People Committed to the Prophet's Teachings for Propagation and Jihad" - was founded in 2002 in Maiduguri, Nigeria. Boko Haram is a separatist movement with a radical Islamic ideology and founded by Muhammad Yusuf. Since 2009, Boko Haram has claimed a large number of lives. The various motives for their rebellious movements are carried out through physical violence, bombings, hostage-taking, and attempts at mass murder (United Nations Security Council, 2014). During the rebellion that occurred until 2015, it 
was noted that the number of deaths in Nigeria reached 20,000 people and caused 2,3 million people to flee and become refugees(Chairunnisa, 2016). Boko Haram insurgency has caused serious damage and threats to Nigerian security and African regional security in general. Currently, more than 13 million who live in Borno, Adamawa, and Yobe, the northeastern states of Nigeria, urgently need immediate assistance(The Cipher Brief, n.d.). Unfortunately, Nigeria has been unable to solve the problem. Thus, humanitarian intervention is needed.

From the background explanation above, this study would like to explain humanitarian military intervention in Nigeria and analyze how the intervener focuses on either the victims or perpetrators. This study will divide in two sub-chapters. First, explaining the development of Boko Haram's attack. Second, this study will explain the humanitarian intervention strategy in Nigeria carried out by The African Union. This study will analyze the strategy of The African Union in Nigeria, whether The African Union uses avoidance strategy, deterrence strategy, defense strategy, compellence strategy, or offence strategy.

\section{RESEARCH METHOD}

The authors used qualitative descriptive data analysis which was intended to describe the situation on the basis of the facts that occurred and then a conclusion was drawn on these facts. In this case the author uses descriptive qualitative research method. As stated by Dr. Lexy J. Moleong, M.A., where the data collected is in the form of words, pictures, and not numbers(Moleong, 2002, p. 6).

\section{THEORETICAL FRAMEWORK}

\section{THE RIGHT OF HUMANITARIAN INTERVENTION}

The humanitarian intervention is the use of force across state borders by a state (or group of state) aimed at preventing or ending widespread and grave violations of the fundamental human rights of individuals other than its own citizens, without the permission of the government of the state whose territory, force is applied(Keohane, $p$ 18 in Okoronye, 2011). Humanitarian intervention should do more good than harm, the victims of tyranny or anarchy must welcome the intervention and also humanitarian intervention should preferably receive the approval or support of the community of democratic states(Teson in Okoronye, 2011).

According to Chapter VII Article 51 of the United Nations Charter, it is stated that(UN Chapter VII Article 51, n.d.): "Nothing in the present Charter shall impair the inherent right of individual or collective self-defence if an armed attack occurs against a Member of the United Nations, until the Security Council has taken measures necessary to maintain international peace and security. Measures taken by Members in the exercise of this right of self-defence shall be immediately reported to the Security Council and shall not in any way affect the authority and responsibility of the Security Council under the present Charter to take at any time such action as it deems necessary in order to maintain or restore international peace and security". Article 51 clearly defines that the presence of international actors for the purpose of intervention is caused by condition of threats in areas like terrorism, threat of drugs, proliferation of weapon of mass destruction, which affects other state's security and in this case, the 
article is applicable to the mentioned threats. Boko Haram is considered a terrorist group, which grants the African Union access to the right of intervening Nigeria. Similarly, the threat of Boko Haram goes beyond the African countries(Mohammed, 2015).

The African Union has the right to intervene their member states based on the Constitutive Act of the Union Article 4 of the Act provides for(Kioko, 2003):

a. The right of the Union to intervene in a Member State pursuant to a decision of the Assembly in respect of grave circumstances, namely: war crimes, genocide, and crimes against humanity;

b. The right of Member States to request intervention from the Union in order to restore peace and security.

\section{THE CATEGORIES OF CRITERIA JUSTIFYING AN INTERVENTION}

Locke and Ladnier (2001) in FP Reports "Building Peace in the $21^{\text {st }}$ Century" describe the categories of criteria justifying an intervention. The authors highlight the categories below:

1. There has been persecution and suppression;

2. Deprivation;

3. Big of loss human life and potentially causing genocide;

4. Gross human rights violations;

5. Crime against humanity is a condition in an areas that occurs murder, extermination, enslavement, forcible transfer of population, severe deprivation, torture, rape, sexual slavery, the crime of apartheid;

6. States fails to manage their country, so militias, warlords, or criminal gangs taking an control to civilian;

7. The illegal and inhumane use of power;

8. International community admits that extreme humanitarian occurs.

\section{THE CONCEPT OF HUMANITARIAN MILITARY INTERVENTION}

Humanitarian crisis occurs when a large number of people are deprived from food, water, shelter, health care, and protection from violence(Seybolt, 2008, p. 38). Seybolt (2008) explains that there are fundamental differences between helping people in a time of war and natural disasters. In humanitarian crises caused by war, the agents of disaster are governments, rebel organization, militias, and armies. There are two considerations on humanitarian crises that occur because of war, namely political consideration and humanitarian consideration. Seybolt (2008), explains that two considerations causes a dilemma on humanitarian intervention. The dilemma is whether the interveners should focus on the victims or perpetrators. Seybolt (2008) explains the objectives and strategies that interveners need to do with two focuses, victims or perpetrators. 
Table 1. Military Response to Humanitarian Dilemmas

\begin{tabular}{|c|c|c|c|}
\hline \multirow{6}{*}{$\begin{array}{l}\text { Humanitarian } \\
\text { Consideration }\end{array}$} & & \multicolumn{2}{|c|}{ Political Considerations } \\
\hline & & Focus on Victims & Focus on Perpetrators \\
\hline & \multirow[b]{2}{*}{$\begin{array}{l}\text { Address } \\
\text { Privation }\end{array}$} & (A) & (B) \\
\hline & & $\begin{array}{l}\text { Objective: assist aid } \\
\text { delivery } \\
\text { Strategy: avoidance of } \\
\text { conflict }\end{array}$ & $\begin{array}{l}\text { Objective: protect aid } \\
\text { operations } \\
\text { Strategies: deterrence, } \\
\text { defence }\end{array}$ \\
\hline & & (C) & (D) \\
\hline & $\begin{array}{l}\text { Address } \\
\text { Violence }\end{array}$ & $\begin{array}{l}\text { Objective: save the victims } \\
\text { Strategies: deterrence, } \\
\text { defence, compellence }\end{array}$ & $\begin{array}{l}\text { Objective: defeat the } \\
\text { perpetrators } \\
\text { Strategies: compellence, } \\
\text { offence }\end{array}$ \\
\hline
\end{tabular}

Source: (Seybolt, 2008)

There are five strategies of humanitarian military intervention(Seybolt, 2008, pp. 4043):

1) Avoidance, the intervener do not engage in direct confrontation;

2) Deterrence, the intervener uses a threat like punishment to the opponent when they take potentially threatening actions. But the threat of punishment must be credible, so the opponent will believe it and avoid taking any actions mainly due to the fear of its consequences (big risks and high costs) they would accept from the punishment;

3) Defence, the intervener uses force to protect something or someone from action that an opponent is taking. This strategy is necessary when deterrence fails;

4) Compellence, the intervener uses threat of force to induce an opponent to take a specified action. The intervener takes initiative actions until the opponent acts. So this strategy applies before the opponent takes any actions;

5) Offense, the intervener uses force to defeat the opponent and offense succeeds when brute force is used.

Seybolt(2008, pp. 43-45) explains that five strategies can be broken down into subtypes or scenarios as shown below:

Table 2. Type, Strategy, and Scenario for Intervener

\begin{tabular}{|c|c|c|c|}
\hline No. & Type & Strategy & Scenario \\
\hline 1) & $\begin{array}{l}\text { Help deliver } \\
\text { aid }\end{array}$ & Avoidance & $\begin{array}{l}\text { Air drops } \\
\text { Camp construction } \\
\text { Direct assistance to population } \\
\text { Transport } \\
\text { Infrastructure repair }\end{array}$ \\
\hline 2) & Protect & Deterrence & Point protection: Escort convoys, Guard \\
\hline
\end{tabular}




\begin{tabular}{|l|l|l|l|}
\hline operations & defence & $\begin{array}{l}\text { building, post, etc } \\
\text { Area protection of small safe areas and } \\
\text { large safe zones }\end{array}$ \\
\hline 3$)$ & $\begin{array}{l}\text { Save } \\
\text { victims }\end{array}$ the & $\begin{array}{l}\text { Deterrence, } \\
\text { defence, } \\
\text { compellence }\end{array}$ and & $\begin{array}{l}\text { Point protection: Safe passage, Buildings, } \\
\text { camps, etc } \\
\text { Area protection of small safe areas and } \\
\text { large safe zones }\end{array}$ \\
\hline 4$)$ & $\begin{array}{l}\text { Defeat the } \\
\text { perpetrators }\end{array}$ & $\begin{array}{l}\text { Compellence and } \\
\text { offence }\end{array}$ & $\begin{array}{l}\text { Negotiated peace } \\
\text { Military defeat }\end{array}$ \\
\hline
\end{tabular}

Source: (Seybolt, 2008)

\section{RESULT AND DISCUSSION}

\section{NIGERIA'S CONDITION AND BOKO HARAM'S ATTACK}

Nigeria succeeded in becoming independent and officially became a British Commonwealth country on October 1, 1960. Nigeria's first leaders at that time were Nnamdi Azikiwe and Abu Bakar Tafawa as prime ministers who were elected by the first parliamentary elections in December 1964. However, the system of government still followed the former legacy of Britain. During its development, Nigeria has repeatedly changed its constitution due to the imbalance of the distribution of development and political results, resulting in demands from various circles of society. However, the amendments to the constitution did not bring significant changes, causing civilians to distrust the state and to form government rebel groups(Chairunnisa, 2016, pp. 36-37). In 1979, there were democratic elections for the first time by civil society in Nigeria. The election was won by Alhaji Shehu Shagari from the National Party of Nigeria (NPN). Meanwhile, the economic conditions in Nigeria, the poverty rate in Nigeria are very high, the inequality of development, and the level of corruption have made Nigeria experience an economic crisis. The highest poverty rates are found in northwestern and northeastern parts of Nigeria. Nigeria is Africa's biggest oil producer, producing more than two million barrels of oil per day, but the country is tainted by corruption and lack of development(VOA Indonesia, 2012).

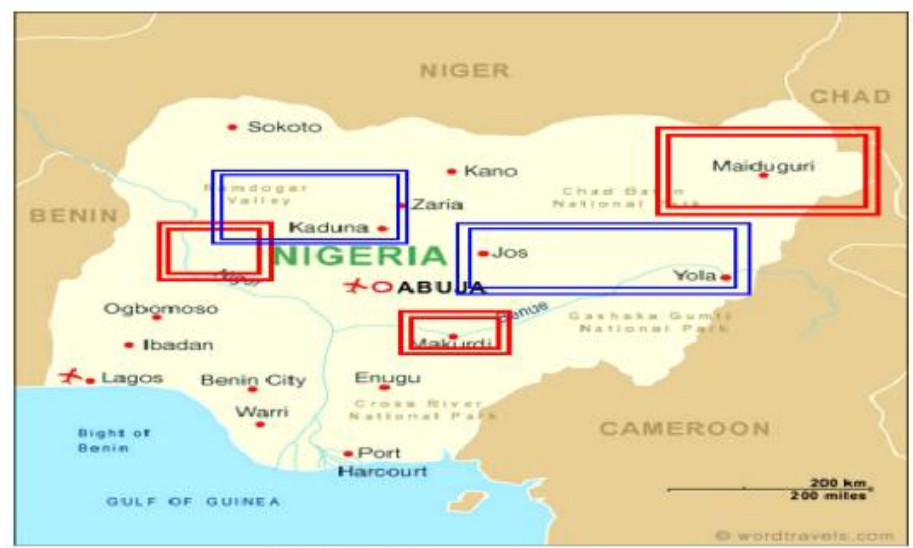

Figure 1. Boko Haram Territory in Nigeria 
Boko Haram was born and formed by a transnational movement with majority Kanuri members on the border of Nigeria and Chad. The phenomenon of the emergence of Boko Haram is a security challenge itself for Nigeria, this movement aims to fight the Nigerian government caused by the dissatisfaction towards the government system that does not apply the puritan Islamic system(Parameswari, 2014). The existence of instability in the government system creates disappointment and a sense of distrust in the officials who are authorized to advance the country. Parameswari (2014) in her research explained that one of the radical groups that finally emerged as rebels in the Nigerian government system was born from the Kanuri ethnic group. Based on the theory of ethnic conflict, ethnic minorities are also the reason for the emergence of internal conflicts. Boko Haram from the Kanuri ethnic group was present on the basis of development discrimination and against the government system which was considered chaotic at that time. One of the radical groups that oppose the government system due to poverty, social and political injustice is Boko Haram, formed and chaired by Muhammad Yusuf in the state of Borno.

Boko Haram or which originally had the name Jama'atu Ahlis Sunna Lidda'awati Wal-Jihad is a group with separatist movements that are also Islamic fundamentalists. This movement has several headquarters located in the Northeastern region of Nigeria, namely the Yobe, Kano, Bauchi, Borno, and Kaduna regions(Annisa, 2018, p. 154). About 1,7 million people remain internally displaced since 2007 Boko Haram's attack in north-east Nigerian states, Borno, Adamwa and Yobe(Hajer, 2018). The authors summarize some Boko Haram attacks in Nigeria from 2009 to 2020 in the table below:

Table 3. Summary of Boko Haram Attacks in Nigeria from 2009 to 2020

\begin{tabular}{|c|c|c|}
\hline Year & Cases & Information \\
\hline 2009 & $\begin{array}{l}\text { The first attack was carried out by Boko Haram in the } \\
\text { city of Bauchi which later spread to the states of } \\
\text { Borno, Kano and Yobe. This violent attack resulted in } \\
\text { the deaths of several local police officers and } \\
\text { approximately } 700 \text { members of Boko Haram, } \\
\text { including its first leader, Muhammad Yusuf. }\end{array}$ & $\begin{array}{l}\text { The leadership of Boko } \\
\text { Haram was later } \\
\text { replaced by Abubakar } \\
\text { Shekau. }\end{array}$ \\
\hline 2010 & $\begin{array}{l}\text { Attacking in Bauchi, this time located in one of the } \\
\text { prisons in Bauchi state with a Boko Haram army of } 50 \\
\text { people. }\end{array}$ & $\begin{array}{l}\text { Boko Haram } \\
\text { successfully released } \\
700 \text { prisoners and } \\
\text { caused } 5 \text { fatalities. }\end{array}$ \\
\hline 2011 & $\begin{array}{l}\text { Frequent bombings at places of worship such as } \\
\text { churches every week. Churches in northeastern } \\
\text { Nigeria were targeted by bombings. In August 2011, } \\
\text { Boko Haram attack was aimed at the UN compound } \\
\text { in Abuja using a car as the applicator for the bomb. }\end{array}$ & $\begin{array}{l}\text { In the } 2011 \text { incident, at } \\
\text { least } 23 \text { fatalities with } \\
75 \text { seriously injured. }\end{array}$ \\
\hline
\end{tabular}




\begin{tabular}{|c|c|c|}
\hline 2012 & $\begin{array}{l}\text { Burning of } 12 \text { schools in the Maiduguri area at night. } \\
\text { Another bomb attack in the city of Kano which targets } \\
\text { of the police, military and prison. }\end{array}$ & $\begin{array}{l}\text { As many as } 10,000 \\
\text { students cannot } \\
\text { continue their studies, } \\
\text { especially in the city of } \\
\text { Kano as many as } 200 \\
\text { people were killed by } \\
\text { the bomb attack. }\end{array}$ \\
\hline 2013 & $\begin{array}{l}\text { Boko Haram fought with the Multi National Joint Task } \\
\text { Force (MNJTF) in the city of Baga, Borno state. Also } \\
\text { kidnapped } 7 \text { foreign nationals of French origin in } \\
\text { January. }\end{array}$ & $\begin{array}{l}200 \text { casualties resulted } \\
\text { from the fighting. }\end{array}$ \\
\hline 2014 & $\begin{array}{l}\text { The kidnapping of } 276 \text { students at Chibok school by } \\
\text { Boko Haram for the purpose of being traded as war } \\
\text { soldiers. In May, Boko Haram attacked } 3 \text { villages in } \\
\text { the Borno region. }\end{array}$ & $\begin{array}{l}\text { The deaths of } 200 \\
\text { Boko Haram militants } \\
\text { as a result of their fight } \\
\text { with civilians. }\end{array}$ \\
\hline 2015 & $\begin{array}{l}\text { Armed violence by Boko Haram attacking a Nigerian } \\
\text { military base. }\end{array}$ & $\begin{array}{l}\text { Caused approximately } \\
1000 \text { casualties }\end{array}$ \\
\hline 2016 & $\begin{array}{l}\text { Boko Haram kidnapped some girls, made video and } \\
\text { then released the video. }\end{array}$ & $\begin{array}{l}\text { Boko Haram share the } \\
\text { video demanding to } \\
\text { exchange their fighters } \\
\text { in prison (caused by } \\
\text { government) }\end{array}$ \\
\hline 2017 & $\begin{array}{l}\text { Boko Haram militants and government bombing each } \\
\text { other }\end{array}$ & $\begin{array}{l}90 \text { people died from } \\
\text { the humanitarian aid } \\
\text { group "Doctor Without } \\
\text { Borders" }\end{array}$ \\
\hline 2018 & Boko Haram militants attack camp in Rann & $\begin{array}{l}\text { Three Nigerian aid } \\
\text { worker killed }\end{array}$ \\
\hline 2018 & Boko Haram kidnapped 1000 children & $\begin{array}{l}\text { The children are from } \\
\text { northeastern Nigeria }\end{array}$ \\
\hline 2019 & $\begin{array}{l}\text { The UN Refugee agency reported } 30,000 \text { people } \\
\text { forced to leave Nigeria }\end{array}$ & $\begin{array}{l}\text { People forced to leave } \\
\text { run to Cameroon } \\
\text { borders }\end{array}$ \\
\hline 2019 & Boko Haram attacked a funeral gathering & About 65 people died \\
\hline 2020 & Boko Haram attack in Borno & About 30 people died \\
\hline 2020 & Boko Haram attacked a village in northeastern Nigeria & $\begin{array}{l}\text { About } 81 \text { people are } \\
\text { killed }\end{array}$ \\
\hline
\end{tabular}

The attacks carried out by Boko Haram were motivated by ethnic and religious conflicts which later developed into violence against civilians. The number of internal conflicts that have led to civil war in Africa itself has become a world concern. For that, it is necessary to carry out a reconstruction by means of humanitarian intervention from those who are indirectly responsible for it. The internal conflict carried out by Boko Haram has a negative impact on civilians in Nigeria. Violence by Boko Haram in the interests of establishing an Islamic state itself has claimed many victims. 


\section{WHY NIGERIA NEEDS INTERVENTION?}

Why does Nigeria need intervention? To answer this question, the authors think the ideal answer is to describe how big the effects and impacts Boko Haram's attack in Nigeria so that intervention is needed. Boko Haram's activities, especially in Northeast Nigeria, are very inhumane which ranges from killing people, destruction of property, and aggression. This situation resulted in 135,000 people flying to neighboring countries, about 35,000 refugees are in northern Cameroon, about 10,000 in Chad, about 90,000 have been displaced to Diffa region in Niger(Relief Web, 2014). Based on the data by the Armed Conflict Location and Event Data Project (ACLED), during the rebellion that took place until 2015, this radical group was responsible for the killing of approximately 20,000 people and caused 2,3 million other residents to become refugees(Chairunnisa, 2016). According to The UN Refugee Agency, there are about 135,000 refugees from Nigerians that fled to Cameroon in 2019(Turner et al., 2019).

In 2020, the total number of deaths from the start of the attack was recorded at 39,249 people(Campbell, 2020). UNICEF said Boko Haram attacks in northeastern Nigeria bring the number of displaced children in the region to 1.4 million(UN News, n.d.). United Nations (UN) Human Rights Council reported that since 2009, Boko Haram has subjected women and girls to widespread and severe forms of abuse, including sexual slavery, sexual violence, forced marriages, forced pregnancies and forced conversions. The group justifies such practices by its conception of the role of women and girls in society. This situation relates with Locke and Ladnier's (2001) description of the categories of criteria justifying an intervention, such as: the presence of persecution and suppression; deprivation; big of loss human life and potentially causing genocide; gross human rights violations; crime against humanity is a condition in an areas that occurs murder, extermination, enslavement, forcible transfer of population, severe deprivation, torture, rape, sexual slavery; and the illegal and inhumane use of power. These criteria continue to occur in Nigeria until now.

In addition, the government fails to manage the condition, so Boko Haram took control of the civilians in Maiduguri, Borno. The map below shows Boko Haram's bases and operations in Nigeria, Niger, Chad, and Cameroon. 


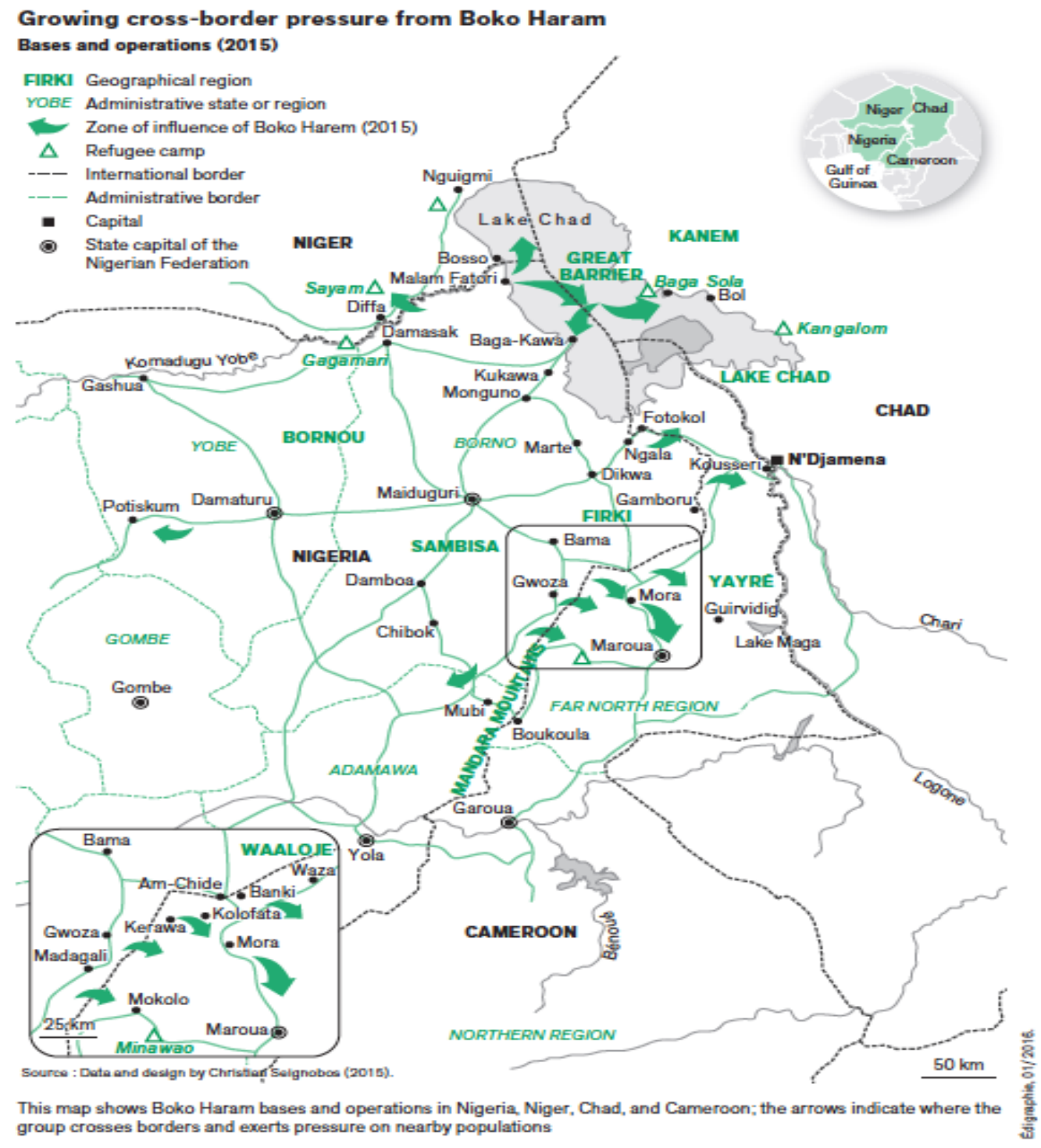

Figure 2. Boko Haram Bases in 2015 (Seignobos, 2015)

The figure describes that the base operation of Boko Haram has been controlling neighboring countries, Niger, Cameroon, and Chad. Boko Haram captured over 20,000 square kilometers of Borno, Yobe, and Adamawa territories(Mohammed, 2015). Boko Haram insurgency has caused loss of lives, deprivation of property and rights to feel secure, and drove a big population to escape to neighboring countries. More than 60,000 refugees escape from Nigeria to Cameroon, Niger, and Chad. Unfortunately, Nigerian government is not strong enough to fight Boko Haram. Thus, The African Union (AU) with member states helps Nigeria. The next chapter will discuss the strategy of AU's intervention. 


\section{STRATEGY THE AFRICAN UNION INTERVENES IN NIGERIA: FOCUS ON VICTIMS OR DEFEAT BOKO HARAM?}

Boko Haram has already killed more than 13,000 people since 2009. Entering 2015, Boko Haram still continue to attack northeastern Nigeria and Lack Chad Basin, thus in January 2015, Nigeria together with neighboring countries, Cameroon, Niger, Chad, and Benin agreed to call AU and ask AU to contact UN Security Council for their support related to the plan to defeat Boko Haram(France24, 2015). The African Union's responsibility is in the form of humanitarian intervention which has been realized since 2014 by the formation of Multinational Joint Task Force (MNTJF) Special Forces that are established in five countries, Nigeria, Cameroon, Chad, Niger and Benin. On $25^{\text {th }}$ May 2015, African Union inaugurated the MNJTF operation with United States' assistance to fight against Boko Haram, which was also backed with European contribution valued about 50,000,000 euros(The African Peace Facility, n.d.). This specific military unit was not only against Boko Haram, but also The Lord's Resistance Army (LRA) that attacked Central African Republic (CAR)(Brubacher et al., 2017, p. 280). The formation of this military unit was also at the request of the UN Security Council under the mandate of counter-terrorism.

The MNJTF has some military tactics namely Operation Lafiya Dole (meaning: Boko Haram must come to an end), also another operation namely Operation Gama Aiki (meaning: Clear all Boko Haram insurgents). The achievement of the MNJTF was a success intaking over the Maiduguri-Digkwa-Gamboru roads in July 2016, after three years of Boko Haram's control(Hairiya, 2017, p. 43).

The African Union has an organ namely The Peace and Security Council (PSC) that is responsible for decision-making regarding prevention, management, and resolution of conflicts(African Union, n.d.). PSC held a meeting on 28 November 2019 about the mandate renewal of MNTJF against Boko Haram. Below are the results of the meeting(Relief Web, 2019):

1. Commends the significant progress by the MNJTF in the fight against Boko Haram terrorist group;

2. Boko Haram still continue threaten the peace and security, so synergy, coordination and collaboration between member states more enhanced;

3. Concerning protect civilians on their territory and resettle the displaced population;

4. Boko Haram use Unmanned Aerial Vehicles (UAVs) for reconnaissance operations within MNTJF area of operation, to this effect, urgently identifying and blocking the source of acquiring these technologies and equipment and blocking any other form military or financial support to Boko Haram;

5. Requests the Commission to make efforts towards mobilizing more additional support for the MNJTF to fill its regional capability gaps especially, CounterImprovised Explosive Devices (CIED) equipment, Amphibious Equipment, counter drones equipment and Information Operation;

6. Deploying efforts towards the protection of human rights.

In addition, the African Union has been providing shelter and other basic services in Nigeria. Apart from basic needs, assistance is also needed to prevent malnutrition among children and rebuild the damaged education system(Chairunnisa, 
2016, p. 9). The African Union is assisted by international organizations such as the United Nations, UNHCR, ICRC, and other international humanitarian NGOs to provide assistance to victims of rebellion, like by providing clean water, food, and health facilities in 2016 and continuing so for the next few years(Saputri, 2018, p. 18). European Union (EU) provided over 700 million euros to support resilience, stabilization and economic recovery, as well as humanitarian assistance within the period of 2016 to2019. This budget was handled by the organ in AU namely The African Peace Facility(The African Peace Facility, n.d.). Humanitarian agencies helped to respond adequately. In Adamawa, Borno, and Yobe, the children have yet to be given their opportunities for schooling. Boko Haram's role in bombing their schools and indiscriminate killing of students and teachers has caused children to be deserted and deprived from their right to access quality education, and more than 5,2 million people in Borno, Adamawa, and Yobe received humanitarian assistance in 2019(United Nations Office for the Coordination of Humanitarian Affairs (UNOCHA), 2015).

From the explanation above, the authors will describe it in the table about the strategy of AU's intervention in Nigeria:

\section{Table 4. Strategy of AU's Intervention in Nigeria}

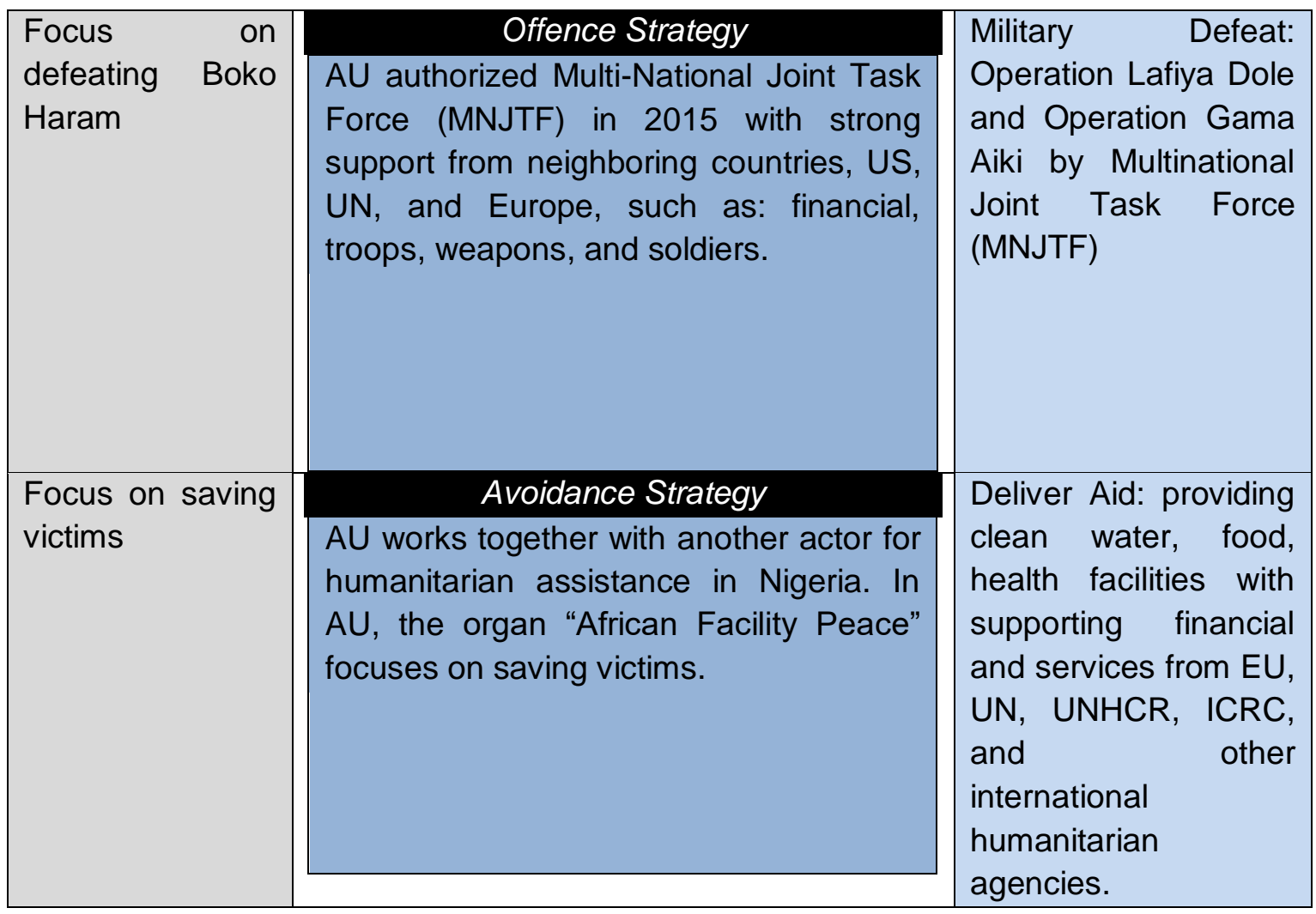




\section{CONCLUSION}

From the explanation that the authors described in previous sub-chapters, this study concludes that Nigerian government's inability to resolve the Boko Haram's insurgency is one of the reasons why humanitarian intervention in Nigeria is needed. Besides, another justification why intervention is needed are because the insurgency of Boko Haram has resulted in big loss of human lives, civilians fleeing to other countries, and even massive destruction of property. Humanitarian intervention in Nigeria was carried out by a regional organization, The African Union (AU). AU has two strategies to help Nigeria, such as: First; AU authorized the military unit operation Multi-National Joint Task Force to intervene Nigeria for the goal of defeating Boko Haram. MNJTF uses the offensive strategy with two military operations named Operation Lafiya Dole and Operation Gama Aiki. Second; AU focuses on saving victims in Nigeria by using avoidance strategy. AU has a special organ in the humanitarian field called African Facility Peace. AU also collaborates with other actors such as UNHCR, UN, EU, and ICRC. Thus, the focus of AU's intervention is to defeat Boko Haram, but it also remains focused on helping the victims.

\section{REFERENCE}

African Union. (n.d.). The Peace \& Security Council. https://au.int/en/psc

Annisa, E. (2018). Upaya Pemerintah Nigeria Dalam Mengatasi Kelompok Radikal Boko Haram. EJournal IImu Hubungan Internasional, 6(1), 153-166. http://ejournal.hi.fisip-unmul.ac.id/site/wp-content/uploads/2017/08/Jurnal Elza Annisa (08-24-17-01-13-09).pdf

Brubacher, M., Damman, E. K., \& Day, C. (2017). The AU Task Forces: an African response to transnational armed groups. The Journal of Modern African Studies, 55(2), 275-299. https://enoughproject.org/wp-content/uploads/2017/08/The-AUTask-Forces-an-African-response-to-transnational-armed-groups.pdf

Campbell, J. (2020, October 12). Nigeria Security Tracker. Council on Foreign Relations. https://www.cfr.org/nigeria/nigeria-security-tracker/p29483

Chairunnisa, L. (2016). Peran Uni Afrika dalam Menangani Kelompok Militan Boko Haram di Nigeria. JOM FISIP, 3(2), 1-12. https://media.neliti.com/media/publications/33258-ID-peran-uni-afrika-dalammenangani-kelompok-militan-boko-haram-di-nigeria.pdf

France24. (2015, January 30). No Title. https://www.france24.com/en/20150130african-union-backs-plan-7500-strong-force-fight-boko-haram

Hairiya, D. (2017). The Role of The Multinational Joint Task Force in Fighting Against Boko Haram in Africa [University of Ghana]. http://ugspace.ug.edu.gh/bitstream/handle/123456789/27586/The Role Of The Multinational Joint Task Force In Fighting Against Book Haram In Africa.pdf?sequence $=1$ \&is Allowed $=y$

Hajer, N. (2018, June 21). What you should know about the humanitarian crisis in north-east Nigeria. Norwegian Refugee Council.

Kioko, B. (2003). The Rights of Intervention under The African Union's Constitutive Act: From non-interference to non-intervention. International Review of the Red Cross, 85(852), 807-825. https://www.icrc.org/en/doc/assets/files/other/irrc_852_kioko.pdf 
Locke, M., \& Ladnier, J. (2001). Criteria for Military Intervention in Internal Wars: The Debate. The Fund for Peace, 2, 1-8. https://www.files.ethz.ch/isn/44292/2001_december_2.pdf

Mohammed, A. (2015). Foreign Intervention in the Fight Against Terrorism: Implications to Nigeria's Sovereignty. In S. Khalid, H. Abdullahi, I. M. Dankani, Y. T. Baba, \& U. Abdulkadir (Eds.), Security, National Integretion and the Challenges of Development in Nigeria. A Publication of the Faculty of Social Sciences, Usmanu Danfodiyo University, Sokoto. https://www.researchgate.net/publication/338702053_Foreing_Intervention_in_the _Fight_Against_Terrorism_Implications_to_Nigeria\%27s_Sovereignty

Moleong, L. (2002). Metodologi Penelitian Kualitatif. Remaja Rosdakarya.

Okoronye, I. (2011). An Appraisal of Humanitarian Intervention Under International Law [Anmabra State University]. https://www.ajol.info/index.php/naujilj/article/view/82394/72549

Parameswari, V. (2014). Terorisme Sebagai Tantangan Kelompok Etnis Terhadap Negara: Studi Kasus Gerakan Transnasional Boko Haram. Jurnal Analisis Hubungan Internasional Universitas Airlangga, 3(1), 679-705. http://journal.unair.ac.id/JAHI@terorisme-sebagai-tantangan-kelompok-etnisterhadap-negara:-studi-kasus-gerakan-transnasional-boko-haram-di-nigeriaarticle-7220-media-131-category-8.html

Relief Web. (2014, January 20). Nigeria: Boko Haram Insurgency. https://reliefweb.int/sites/reliefweb.int/files/resources/b-acaps-briefing-note-nigeriaboko-haram-insurgency.pdf

Relief Web. (2019, November 28). Communique Adopted by the Peace and Security Council (PSC). https://reliefweb.int/report/nigeria/communiqu-adopted-peace-andsecurity-council-psc-african-union-au-its-898th-meeting

Saputri, D. W. (2018). Upaya Uni Afrika dalam Menangani Dampak Kelompok Boko Haram di Nigeria 2009-2015. http://repository.umy.ac.id/handle/123456789/19004

Seignobos, C. (2015). Boko Haram and Lake Chad: An Extension or a Sanctuary? Afrique Contemporain, 255(3), 89-114. https://www.cairn-int.info/journal-afriquecontemporaine-2015-3-page-89.htm

Seybolt, T. B. (2008). Humanitarian Military Intervention The Condition for Success and Failure. Sipri Oxford University Press.

The African Peace Facility. (n.d.). Factsheet Multi-National Jpint Task Force (MNJTF) against Boko Haram. https://africa-eupartnership.org/sites/default/files/apf_factsheet_-_mnjtf.pdf

The Cipher Brief. (n.d.). Northeast Nigeria's Growing Insecurity Threatens Humanitarian Aid Workers and Civilians. https://www.thecipherbrief.com/column_article/northeast-nigerias-growinginsecurity-threatens-humanitarian-aid-workers-and-civilians

Turner, V., Kigali, W., Kolopp, C., \& Bourgois, X. (2019, February 11). Nigerian refugees struggle in aftermath of Boko Haram attacks. United Nations High Commissioner for Refugees (UNHCR). https://www.unhcr.org/news/stories/2019/2/5c6139e74/nigerian-refugees-struggleaftermath-boko-haram-attacks.html

UN Chapter VII Article 51. (n.d.). https://www.un.org/en/sections/un-charter/chaptervii/index.html 
UN News. (n.d.). Boko Haram violence displaces 1.4 million children in Nigeria and beyond - UNICEF. https://www.un.org/africarenewal/news/boko-haram-violencedisplaces-14-million-children-nigeria-and-beyond---unicef

United Nations Office for the Coordination of Humanitarian Affairs (UNOCHA). (2015). Humanitarian needs overview Nigeria. https://www.unocha.org/sites/dms/ROWCA/Coordination/HNOs/HNO Nigeria 15March2015.pdf

United Nations Security Council. (2014). Jama'atu Ahlis-Sunna Lidda'awati Wal-Jihad. https://www.un.org/securitycouncil/sanctions/1267/aq_sanctions_list/summaries/e ntity/jama\%27atu-ahlis-sunna-lidda\%27awati-wal-jihad-\%28boko

VOA Indonesia. (2012, February 13). Angka Kemiskinan Meningkat di Nigeria. https://www.voaindonesia.com/a/angka-kemiskinan-meningkat-di-nigeria-139263573/104870.html

World Poverty Clock. (2018). Nigeria has the largest extreme poverty population. https://theatlas.com/charts/Hynnu6C-7 